ROCZNIKI HUMANISTYCZNE

Tom LXVIII, zeszyt $11-2020$

DOI: https://doi.org/10.18290/rh206811-8

JAN KŁOS

\title{
THE GENII LOCORUM AS THE NECESSARY SPACE AND PLACE FOR HUMAN DEVELOPMENT*
}

\begin{abstract}
A b s t r a c t. This text focuses on the prominent Victorian figure, John Henry Newman (1801-1890), and how he responded to his ethos. It is assumed here that each person grows in confrontation with his or her place. The place in which we live, our genius loci, exerts some influence on our decisions. The most important thing is to find out what kind system is thus established. This system may be true or false. Newman valued highly his family home, his university friendships, and the Church as his ultimate destination. He was born in the Anglican Church at the time when the Anglican milieu was particularly hostile towards the Roman Catholics. His personal history is so fascinating because despite the surrounding hostilities, he managed to re-evaluate his life.
\end{abstract}

Keywords: Church; ethos; genii locorum; Newman; person; place.

Because I know that time is always time And place is always and only place And what is actual is actual only for one time And only for one place I rejoice that things are as they are...

T. S. Eliot, Ash Wednesday

\section{INTRODUCTION}

Freedom is a natural context of human action. The acting human being experiences it at every level of his action: personal, social, and political. We always act within certain structural restrictions or obstacles. They may be

JAN KŁOS, PhD, Habil., The John Paul II Catholic University of Lublin, Faculty of Philosophy; address for correspondence: Al. Racławickie 14, 20-95 Lublin, Poland; e-mail: jan.klos@kul.pl; ORCID: https://orcid.org/0000-0002-8043-3820.

* The project is funded by the Minister of Science and Higher Education under the programme "Regional Initiative of Excellence" for 2019-2022, no. 028/RID/2018/19; the amount of funding: 11,742,500 PLN. 
more or less obstructive. Indeed, our freedom is continually put to the test under concrete circumstances and in concrete places as their scenography. Therefore, it may be considered in its negative and positive aspects, as we know from the well-known essay by Isaiah Berlin (Berlin passim). In its negative aspect, also called freedom from, it denotes the external (usually political) conditions of human action. In this respect, we say that human persons are not coerced or in any other way thwarted in their action, as long as they do not encroach upon the same rights for free action in other persons. Now in its positive aspect, called freedom to, we say that human persons are free to choose what is presented by their intellect as good. In the latter case the person finds no internal obstacles to act according to what they have recognized as their duty; they are not hindered in choosing the good they have deemed right to follow.

Freedom is typically posited of human beings as creatures endowed with the capacity for rational choice and will. Rational choice in turn presupposes some negotiations between different options. If I am supposed to choose between $\mathrm{A}$ and $\mathrm{B}$, I need to know the value of either choice. Therefore, limitation is written into human freedom. If I choose A, I opt out of B; and if I have decided for B, I have at the same time rejected A. I cannot have both: I should not regret the one when I have chosen the other. Likewise, any natural obstacles, e.g., that I cannot afford a luxurious car, are ruled out as genuine hindrances to our liberty. It is true, we may find it difficult to perform our duties in some socio-political contexts, indeed there are concrete milieus which can even be destructive. However, my primary concern is myself, for it is with myself that I am supposed to grow and develop into maturity; I use myself, my natural endowments and capacities with which to brave the exigencies of reality. Therefore, if I cannot use myself to the full potential of my capacities or else I am forced to keep up the pretence that I hold certain opinions and favour some solutions whereas the opposite is true, and I cannot reform the place in which I live, then I need to leave it, for it has thus forced me to be untrue and unreal. If there is a place that makes me false, I had better leave it. Each place has its genius loci, a respective spiritual and intellectual climate which is either conducive or hostile to a person's growth into maturity.

I would like to consider space and place as the components of personal ethos in the prominent Victorian, John Henry Newman (1801-1890). His life is an exemplar of how the individual person is at times called to re-evaluate his world and take this re-evaluation as a special personal task. Newman's life can be considered in three essential contexts: his family, his friends and 
teachers, and the Church; all these spheres are combined, organized, and taken advantage of by the acting self. These are the primary spheres which for Newman, like all humans an active and not simply receptive being, freely grew into the person he became endowed with respective faculties with which to evaluate the matters at hand.

We must bear it in mind that the nineteenth century no longer believed in the universal context of the enlightened ahistorical individual. The individual does need an appropriate milieu for his respective growth. Newman comes to maturity and to his weighty decisions in confrontation with the three contexts I have mentioned above. They constitute the ethos, good or ill, which is the stage upon which he acted the drama of his life; Newman never complained of his circumstances as a particularly difficult plight. Each individual person has his respective tasks with which to cope. Thinking about himself as someone especially chosen for suffering might have pushed him towards ostentation or despair, things he always sought to avoid. Only by treating individual circumstances as natural, can one set oneself to the task. The right ethos provides conditions, leaving at the same time enough space for the individuals to make their own decisions.

James Pereiro, a Research Fellow at the University of Navarra, notes in his monograph on the Oxford Movement that Newman "was a great believer in the existence of genii locorum" (Pereiro 15). Each genius loci is a system for the individual to recognize its underlying structure, the elements of which can be incorporated in the individual's life or rejected. Such places were his family home; Oxford University and the scholars with whom he initiated the movement designed to renew the Anglican Church, and, eventually, the Roman Catholic Church he decided to join. None of these places simply determine the human person. They are rather stages, each with their unique character, set for the person to carry on his individual journey. The stages are peopled with various characters, so each encounter is an opportunity for an interpersonal exchange.

\section{THE FAMILY - THE PLACE OF CHILDHOOD}

The family is the first milieu in which one's personality takes shape. The basic preconditions are love and freedom. Love can be understood here as acceptance and respect for one's individual development. The young person is in the beginning of his journey through life. No one can be prepared in advance for whatever decisions they are supposed to make. The only thing 
that is needed is an integrated personality (i.e., intellectually and morally prepared) or, as Newman understood it, with the intellect and will living under one roof. That is why the characteristic trait of Newman's thinking was his "systematic" approach. Instead of concentrating on some isolated aspects he would rather look at the whole of a process, an organism, ultimately, the whole human being. He sought the system hidden behind the visible appearances.

Newman was the oldest in the family of six children (three daughters and three sons). He was born in London. As he was the oldest child in the family, so naturally he must have learned to take on many duties. As far as the atmosphere of his home is concerned, his parents "were musical, fond of plays, of dancing, of reading and of conversation" (Trevor 7). They loved each other and were delighted with their children. They were tolerant and open-minded, allowing them free development, without imposing on them excessive ambitions just to please their parents' or any others' expectations. Therefore, "there was no forcing, moral or intellectual, no strain of living up to high adult standards" (Trevor 7). Such traits must have left an indelible mark on John Henry, since the underlying principle of his later life was a belief that every individual person has his own way of development, his personal effort to make, and his personal result to obtain. In his most philosophical work, An Essay in Aid of a Grammar of Assent, he stressed that thinking is "a personal result ... in each case ... so idiosyncratic in its circumstances, that it would stand by itself, a special formation, unconnected with any law..." (Newman, Grammar 85). Thus, each person has their own individual way to assent to some general truths, for each person is immersed in their idiosyncratic worlds. We all need to take up our individual work to assent to and to realize the truth. As Newman observed: "Now it is doubtless a great mystery, why this man receives the truth and practices it, and that man does not. We do not know how it comes to pass; but surely we do not tend to solve it, by saying God has so decreed it. If you say that God does absolutely choose the one and reject the other, then that becomes the mystery" (Newman, Plain and Parochial 1112).

As a family, the Newmans naturally felt a strong responsibility for one another. John Henry worked to help his relatives, when his father went bankrupt or when his brother, Frank, had problems; Frank was in danger of losing his faith in the Holy Trinity because, unlike John Henry, he was still in the grips of "the wretched principle of private judgment" (Trevor 156). He was on very good terms with his sisters, especially Mary. Newman was often criticized for being too self-centred, but his life provides evidence to the con- 
trary. As his biographer, Meriol Trevor, observes, "a self-centred man is not himself the centre of a wide circle of friends, as Newman was from his boyhood to his death, friends of both sexes and all ages, and from different social and national backgrounds. The self was the centre of action, as it must be for everyone - and he knew more about its motives than most-but the centre of love was in another: in Christ" (Trevor 4). It is very important to note that despite his personal attachment to his family, the future cardinal felt free to choose his own way, even though it was at time contrary to his relatives' expectations (especially his decision to join the Roman Catholic Church).

It is at his family home that he learned to be considerate and understanding of other people and, primarily, to be responsible for himself. First of all, he experienced acceptance, compassion, and love, the basic elements with which to brave the hardships of living, i.e., the changing and revolutionary re-evaluations of his epoch, and his personal challenges as well. It is from observing and living with other people that the future cardinal learned that each individual has his own peculiar way with which to evaluate life and to accept certain truths. I think it is in the context of his family life that he first understood that it is not enough to provide some theoretical arguments on behalf of certain choices, an effort that can merely result in a very superficial notional assent, but which does not touch the inmost depth of the human person. There are truths into which the person must grow. Therefore, when he had grown to his decision to join the Roman Catholic Church in 1845, he would never have thought about proselytising among his family members; they were simply in an entirely different place, not in a physical sense, that is. The person who has realized a truth as his personal calling and the person who has no such understanding are like two radically different worlds, as if they were using different languages. His sister Jemima was very critical of Newman's decision. His sister Harriett also bemoaned this fact, and Jemima asked a dramatic question: "What can become worse than this? It is like hearing that some dear friend must die. I cannot shut my eyes to this overpowering event that threatens any longer" (Trevor 349). His sister Mary had long been dead when her brother joined the Roman Catholic Church (she died prematurely in 1828, at the age of nineteen).

Another trait of his character that he learned in childhood was that "he carefully recorded the influence of others upon him..." (Trevor 5). That is why the awareness that we are living among other persons dominates in his interpretation of human knowledge. He holds that the processes of learning resembles the process of personal interpenetration. This process is especially 
effective when we are confronted with someone who has really assented to a truth, who has thus realized it in himself, and who can thereby be a witness to it. Such a person is a paradigm of examples rather than an abled provider of arguments. Being exposed to a living example is much more powerful than having to respond to an intellectual argumentation.

Examples move and mollify us, arguments are often accepted in a superficial manner (the fact that we cannot refute them does not mean that we accept them), thereby they are too weak to touch our interior. Newman has rightly noted that the same argument effects a different, sometimes completely different, reaction in two different persons. This fact made him aware that the force of argument does not consist completely in its explicit form, but in the implicit preparation of the person who is exposed to it. Therefore, although it obviously pained him that his family were against his decision to become a Catholic (his brother Frank even thought that it was a wellcalculated step to obtain something in return), Newman could account for it by the fact that they were simply in different positions of understanding their religious duties.

Newman's memories from childhood testify to his very vivid imagination. We read in his Apologia that he "used to wish the Arabian Tales were true: my imagination ran on unknown influences, on magical powers, and talismans.... I thought life might be a dream, or I an Angel, and all this world a deception, my fellow-angels by a playful device concealing themselves from me, and deceiving me with the semblance of a material world" (Newman, Apologia 1). We find here an excellent description of a romantic imagination. His hesitation between the reality of material and spiritual beings is later manifested in his spectacular conversion in 1816, when he came to believe more in the world unseen than in the visible surrounding. Let me stress again the fact that each individual life should be taken in its idiosyncratic course, in its whole and system-making structure. In his Apologia the author seems to be looking at himself as one object of curious scrutiny, enumerating all the elements that came to compose its unique course. The individual is born to a concrete family, an event that is beyond his choice, but then-as he grows - he becomes more and more responsible for his decisions, that is, for his reality or unreality.

It is interesting to note that in the school he attended there were very few Catholics. He was not even aware who they were. In general, the school was free "from Catholic ideas" (Apologia 2). He once visited a Catholic chapel and all he later recollected from this visit was a pulpit, a preacher, and a censer. 
I am listing these symbols of an unknown place that wrought an impression on the mind of the young boy. Each place has its characteristic elements. Each place emanates with its own unique spirit, indeed its genius loci. They penetrate the mind of the one who searches for truth with their mysterious and unwavering power. Newman calls such elements unperceived impressions which "unconsciously [supply] the mind with spiritual life and peace" (Fifteen Sermons 322).

We can say that Newman's home was a place of strong interpersonal relations. In other words, it supplied the right ethos for the development of John Henry's loyalty and responsibility. Let us say, an opportunity, for no ethos is so determining that each of its members grows in the same manner. Another critic of nineteenth-century cultural transformations described it beautifully when he wrote in his most famous essay: "The father and mother, between whom God placed no other intercourse but love, create between themselves the intercourse of severe ceremony; whilst a sacrilegious familiarity suppresses the distance God placed between children and parents, destroying the intercourse of reverence. The family, then, debased and profaned, is dispersed and lost in the clubs and casinos" (Cortés, Essays 33). For sure, Newman's home in no way resembled the false places of clubs and casinos in which no intimate or solid relationships can be established.

\section{FRIENDS AND TEACHERS-THE PLACE OF EDUCATION}

It follows from our considerations so far that personal encounters and examples were of utmost importance for Newman. Theoretical truths translated into practical principles that rule over one's conduct exert influence on others: they can enrich or impoverish them. This is the main reason why our hero valued friendships so much. Out of his numerous friends and teachers, we should mention Richard Whately, Hurrell Froude, John Keble, and Ambrose St John. Whately — as Newman himself affirms — "opened my mind, and taught me to think and to use my reason" (Newman, Apologia 7). He understood the Church of England "as the one, historic, and uninterrupted Church, which was a great sacred corporate body, separate from the State," and, as Vélez acknowledges, his "sharp criticism of the Church of England was an important lesson for Newman, who was gradually beginning to understand Anglicanism's Catholic heritage." All these elements led Newman "to conclude 
that Roman Catholicism alone was able to safeguard the truths that they sought to defend" (Passion for Truth 8).

Under the influence of his mentor, however, he was also inclined towards the School of Noetics, a circle of intellectual liberals at Oxford. As he noted in his Apologia, "I was beginning to prefer intellectual excellence to moral," a dream from which he was awakened in 1827 by "illness and bereavement" (9). He realized that when intellectual prowess and scoring debating points in the heat of a discussion are all that matter, the outcome is hazardous for the person as a whole. One wins only a qualified victory, which may even be dangerous for the spiritual integrity of the person. It may strengthen them in wrong views, while being at the same time a reward for a self-confident conceit.

Newman was open to new views and influences. Armed with a penetrating mind apt to synthesise, and a sensitive conscience, he was, however, independent in his personal decisions. The mind thus immersed in all these intellectual processes, assuming that it is not closed to them, is capable of taking advantage of them for its own growth. Certain truths, once they become one's own, they can be turned into certitudes. His friends made Newman aware of the Church as a spiritual place. After the schism of Henry VIII, the Church gradually became a lay institution. With the ruler as its head and the clergy involved in mundane affairs, this outcome was too obvious. I shall say more on that in point three. Let us also note in passing that whatever influences there are, they must fall on a fertile ground in order to take root. Undoubtedly, John Henry was such a ground.

Owing to his new and dramatic experiences Newman diverged in opinion from the logician Richard Whately and his rationalism and came closer to Keble's and Froude's religious ideas (Vélez 118). Froude, especially his journal, played an important role in the development of the Oxford Movement (1833-1845). Froude's submission to the Church had checked the pride of rationalism. Newman admired his Remains in which the author recommended going back to the "universal consent," that is, to the moment when Christianity was united. It was then by reading Froude that Newman "felt that in religion, moral and religious truth is communicated by the power of a 'personal presence'; an abstraction is too cold to move the heart" (Pereiro 58). This quote is indeed redolent of the romantic climate; we must remember that the nineteenth century was a stage upon which the Enlightenment ideas clashed with the romantic mood. An abstract principle may indeed appeal to the intellect, and it may even be difficult to refute it for some logical reasons, but then it appears to be helpless in convincing the person. This conclusion, 
undoubtedly borrowed from Froude, was a strong theme throughout Newman's writing. The person who realizes the truth becomes an especially powerful centre of attraction. This is so not in the sense of making the truth subjective, but in the sense of giving it a concrete personal colour.

Keble, for his part, was convinced that "the search for truth could not be separated from the pursuit of goodness" and "moral uprightness was a fundamental condition for clear intellectual perception..." (Pereiro 14). Such positions agreed later with Newman's claim that there is a certain connatural relationship between the mind and idea. If we consider moral matters, it comes only as natural that we should consider a certain kinship between the idea and moral behaviour of the person who holds it. The idea must be "congenial to it" or, as Newman explains it, if "there is that preparation of mind, the thought does lead to the act" (Newman, Grammar 82).

It is fitting that we should refer here to some elements of Newman's epistemology. The original situation of the human intellect is that of functional disarrangement in which ideas and emotions, inclinations and disinclinations struggle for priority. As Newman put it in his Tamworth lectures, "the human mind is at best in a very unformed or disordered state; passions and conscience, likings and reason, conflicting - might rising against right, with the prospect of things getting worse" (Newman, Discussions 263). Such being the condition, we need a stronghold to lean on. With this context in mind, James Pereiro rightly observes, "the wounded and darkened intellect needs the guidance of right moral feeling or ethos to find its way" (Pereiro 30). This perception appears to run counter the modern spirit of rationalistic empiricism for which the free interplay of ideas was most important. Newman would say that this might be the case if we were dealing with a perfect intellect. The intellect of the fallen creature, however, when involved in the immanent world of its ideas, may arrive at truth or falsehood quite independently of the reality of facts; it may hold opinions which have no ground in the person.

This is especially true in the case of notional assents (as set in opposition to real assents), when we often keep a distance from the realities about which we are so prone to express our opinions, although we fail to realize them. Therefore, we frequently fall into unreality, and - as Newman observed:

[I]nstead of speaking out their own thoughts, they suffer the world's opinion to hang upon them as a load, or the influence of some system of religion which is in vogue. It very frequently happens that ten thousand people all say what not any one of them feels, but each says it because every one else says it, and each fears not to say it lest 
he should incur the censure of all the rest. Such are very commonly what are called the opinions of the age. (Plain and Parochial 1028)

I would like to stress this fact of looking for a system, the whole, instead of trying to concentrate on single aspects. It is my understanding of Newman that, for him, it does not matter so much what individual people say, but what system lies behind their views. If the system is wrong, individual opinions simply naturally follow as its consequence. The point is then to make people realize what kind of system they follow.

In notional assent the acting principle is often public opinion; many people hold on to it without even understanding what they are saying. And thus the distance is created and a certain superficiality forces its way in between the agent and his words, "ways of speech come in, and modes of thought quite alien to the minds of those who give in to them, who feel them to be unreal, unnatural, and uncongenial to themselves, but consider themselves obliged, often from the most religious principles, not to confess their feelings about them. They dare not say, they dare not even realize to themselves their own judgments. Thus, it is that the world cuts off the intercourse between soul and soul, and substitutes idols of its own for the one true Image of Christ, in and through which only souls can sympathise" (Newman, Plain and Parochial 1028-1029).

It follows that we may be living in an empty world, i.e., a world in which there are no real people. Such an outcome has been described by many existentialist philosophers. In the nineteenth century, it found its most ardent exponent in the Danish philosopher, Søren Kierkegaard.

The truth has its natural place in the human person. Once it is realized by this person, it becomes the moving principle, the underlying ground of all the other acts. Members of the Oxford Movement gradually discovered that they found this climate of personal influence in the primitive Church. It was then that the Church was not so much ruled by written principles as by living examples and genuine witnesses. Confronted by a witness, i.e., someone who, say, is ready to lay down their life for something. One can ignore an abstract principle, but it is hard to ignore a testimony.

John Henry Newman stresses this element of temporal growth and engagement. He writes in one of his sermons "that justification must be in man if it is to profit him" (Plain and Parochial 1038). The person, understood as an idiosyncratic history, is unlike the modern punctual self. Such a self is an easy rider whose principal attitude is disengagement from any external obligations 
except those created by the mind (Taylor 159-76). The punctual self has no need of a place, for it proclaims universality rather than particularity. The modern punctual self is ahistorical, for it is reduced to consciousness. I create myself by creating a string of ratiocination on behalf of an opinion. For such a self to exist it suffices to have a coherent set of ideas.

Newman puts it clearly: the reason why certain people receive the truth is "a great mystery." If it is a mystery, then if they reject the truth is a mystery as well. It cannot be compensated by further logical argumentation and additional facts provided. A question that begs an answer is how to, or whether in general we can, create appropriate conditions for the acceptance of the truth. Can we create a respective ethos? This ethos may be composed of good education, helpful and considerate parents, the right friends. Such factors indeed are helpful, but we can have examples to the contrary, i.e., those who lacked those positive contributions and yet, when given the truth, were capable of receiving it.

When Newman was employed at Oriel in 1826, he immediately noticed that Oxford University was a malfunctioning system: with atrophy of moral tuition and hypertrophy of intellectual instruction. The university authorities turned a blind eye to students' misconduct (Vélez 123). ${ }^{1}$ A vigorous education in the Classics was no longer appreciated in the Victorian period. In line with modern thinking (disengagement), in line with the liberal and utilitarian approach the authorities believed that it was enough to provide theoretical knowledge and each individual would be able to behave uprightly. Newman provided a very critical analysis of this kind of attitude of, say, ethical intellectualism in a series of lectures, which I have already mentioned, entitled The Tamworth Reading Room (then included in his Discussions and Arguments). Let us look at some of Newman's critical remarks: "To know is one thing, to do is another; the two things are altogether distinct.... [The] consciousness of a duty is not all one with the performance of it... men may become wiser, without becoming better." And the outcome was all too obvious: "Not a victory of the mind over itself-not the supremacy of the law - not the reduction of the rebels - not the unity of our complex naturenot an harmonizing of the chaos-but the mere lulling of the passions to rest by turning the course of thought; not a change of character, but a mere removal of temptation... not inward change was contemplated, but a change of external objects" (Newman, Discussions 262, 264, 265).

\footnotetext{
${ }^{1}$ It is interesting to note that already Thomas Hobbes (in the seventeenth century!) called Oxford "a breeding place for left-wing Radicals."
} 
Classical education was rejected on behalf of science and practical knowledge. Therefore Newman, together with other Tutors (Hurrell Froude and Robert I. Wilberforce), sought to reform the system of Tutorship. They focused on "the pre-eminence of the Tutor's role in the moral and religious education of students by means of personal influence and friendship" (Vélez 125). This is very much akin to Newman's firm belief that personal examples are much more powerful methods of moral education than theoretical considerations. He represented a more pastoral (than merely intellectual) approach to Tutorship. Anyone acquainted with Aristotle's teaching on virtue can immediately notice that we find here the ancient Philosopher's remark that the point is not to know what virtue is but to be a virtuous person.

Newman realized that just like in the natural sciences we need to rely on induction in our investigation, likewise in the sphere of moral education one needs a respective method. We need authority, tradition and analogy just like in science we resort to facts (Vélez 42-43). Thus, this eminent Victorian struggled to save religion from its descent to sentimentalism and irrationality, the two dangers in the era of Romanticism. Religion had to find some rational grounds for its existence in the age of spectacular scientific and technological endeavours. Mere intellectual and logical foundations were found wanting. I think that Newman realized with his utmost perspicacity that a rigorous mind was insufficient. In religion we need holy people, just like in morality we need moral people. Otherwise a consistent exposition of certain principles is far insufficient in such areas.

Since the human mind is in functional disarrangement, therefore it cannot be left alone with an array of open options with no hint as to which options are good and which are bad. Such a mind needs personal influence and friendship, as we have already noted. I think that Newman's decision to join the Roman Catholic Church was caused by the fact that he found in this Church a firm dogmatic structure on which such a wobbly creature can rely. When he embarked on studying the history of the primitive Church, he found out the role of simple people clinging firmly to orthodoxy while hierarchs were going astray. It is my belief that such a circumstance could have made Newman think that it was the genius loci of the Roman Church that gave rise to such integrated beings. The Roman Church was independent of the State and its structure was dynamic and free from the encroachments of modern philosophy, so perilous for religion in its supernatural claims.

Newman was confronted with firm opposition in his endeavours to impose discipline. Provost Hawkins assigned no students to his class, and the 
young Fellow was left with no one to teach. It was at that time that he had received a gift of thirty-six volumes of Church Fathers. The rejection of his tutorship turned out to be a blessing for him. He had more time to study the history of the united Church. Had he not been expelled from Tutorship, the Oxford Movement would not have started. First of all, his way to the Roman Catholic Church would not have started.

\section{THE CHURCH-THE STRONGHOLD OF DOGMAS}

Because Newman believed in the spirit of the place where people live, because he sought to made them more active and be committed to the life of the Church no wonder he was called a predecessor of the Second Vatican Council. It follows from his belief that the lay people must be made active in many spheres of the Church, for they are living examples of faith (the religious truth seeks to be given shape by concrete persons). Believers should turn their faith into practice, should create the respective milieu in which it would be easier to experience the testimony of the faithful, to exchange opinions, and to create a living forum of interpersonal relations. Newman himself was drawn into many controversies when he felt called to testify. Primarily, he testified to his own person. As regards the Church, the basic question was the place of the laity in the Church, a topical issue of the Second Vatican Council. Newman went even deeper than that, for the question about the place of the laity, as Coulson notes, "raised deeper issues about the nature of the Church itself." He then came up with his "conception of the width of the Christian community" which "had formed the basis of his policy of associating clergy and laity in a common higher education; and it was what caused him to support the educated laity in their effort to discuss the relationship of the Church to its context within a new and challenging society" (Coulson 103).

All these elements had created the mind of the Church. We need to bear in mind the social context of the nineteenth century and the hostile climate to the Church. In the area of science we have Darwin's theory of evolution (published in $1859^{2}$ ); in the area of social matters one should mention Marx's communist manifesto (1848). The Church took up a defensive position, constantly pushed back by the encroaching revolutionary spirit of social change.

\footnotetext{
${ }^{2}$ It is interesting to note that in the same year Newman published his article On Consulting the Faithful in Matters of Doctrine in the Catholic monthly Rambler.
} 
Newman seemed to have been prepared like hardly anybody else for the task. He came from the tradition of British empiricism, the modern initiator of all these disquieting changes. He developed the idea of evolution in his Essay on the Development of Christian Doctrine, so he was well-acquainted with evolution.

It is true that John Locke proclaimed the attitude of toleration for all religions, but at the same time he recommended one religion for the State, namely that of the State's ruler. Then, slowly but surely, the Church was made a political partner of the State, with its spiritual dimension made subordinate and of secondary importance. Religions was made a mere private choice, then it became a matter of some reasoned choice rather than a matter of the Revealed Word and Christian tradition. All these elements create the ideological genius loci of the modern world. The ego cogito of modern philosophy indeed performed the work of levelling, completely ignorant of the idiosyncrasy of the Church as a natural and supernatural institution.

Newman sought to restore the Church to its place. He came from the Protestant tradition where it was natural to leave for the believer room to decide. The thing of utmost importance was that, to be on the safe side, this believer must speak out of the depth of his faith and commitment. Thus, his opinion cannot be just a matter of intellectual weight, but rather a question of testimony. Such a believer must be imbued with the living faith. Then the clergy and the laity can create the Church as a community of witnesses, of those who really assent to the truth, hold it, and realize it in their lives. The Church is not a place of debating various points of view. At least, this is not its principal function, not its main spirit.

The main point of controversy following the publication of his paper was caused by Newman's ardent wish "to see the Church take advantage of its emancipation and become, once again, a community on the march" (Coulson 110). We are talking of the Catholic emancipation in Britain. At the same time let us observe that Newman seemed to have continued the course of renewal that was originally intended to put the Anglican Church on its spiritual track. In general, then, Newman's task, as he himself saw it, was on the one hand to restore the Church and then to bring the Church to the world so that it could spiritualize it.

Here again when speaking about the Anglican Church and its genius loci, Newman addressed it as a system with its unique philosophical and spiritual foundation. And he came to a conclusion that if the foundation was wrong, the views held within its confines were false as well. He realized that the Anglican Church could no longer be treated as a Via Media between the 
Roman Catholic Church and Protestant dissenters; rather, it was the question of "either-or." Describing the members of the Oxford Movement (or Tractarians, as they were also defined), the future cardinal noted:

In truth, when they feared that the good seed would fall, not on a congenial soil, but on hard, or stony, or occupied ground, they were fearing that the National Church, though they did not use the word, had no life. Life consists or manifests itself in activity of principle. There are various kinds of life.... The life of a plant is not the same as the life of an animated being.... nor is the life of the intellect the same in kind as the life of grace; nor is the life of the Church the same as the life of the State.

Newman continues, trying to define with an ironic overtone the genius loci congenial to the Anglican Church:

If then 'life' means strength, activity, energy, and well-being of any kind whatever, in that case doubtless the national religion is alive.... In all parts of the world it is the religion of gentlemen, of scholars, of men of substance, and men of no personal faith at all... if indeed it is the life of religion to be the first jewel in the Queen's crown, and the highest step of her throne, then doubtless the National Church is replete, it overflows with life; but the question has still to be answered, Life of what kind? (Certain 43-47)

The Anglican faith was enfeebled by the heritage of modern philosophy in the form of latitudinarianism and comprehensiveness of belief wherein all views are accepted as long as they fall under the sovereign rule of the individual. We can see quite clearly Newman's point, i.e., how a false principle creates a wrong system. As I have already alluded here to Newman's main trait of his character, he firmly believed in the result of thinking as personal result, therefore he was not engaged in any kind of proselytising. When he noticed that the ethos he was living in was false, he was ready to leave it. Hence when he realized that the Anglican Church had no spiritual life, he left it because "what mattered was to be living in the Church which Christ founded, and if the Church of England was not it, there was no point in men trying to make it so" (Trevor 309).

What Newman criticized in the Anglican Church he did not want to find in the Catholic Church. Simpson comments on the situation of the laity in the Roman Church: "The laity are to be kept in ignorance of all religious questions except those in the catechism, in order to misuse their obedience to a body of directors professionally educated to manage their religion for them. Religion is turned into administration, the clergy into theological police, and 
the body of thinking laymen into a mass of suspects, supposed to be brooding on nothing but revolution, and only kept together by motives of fear, and by the external pressure of a clerical organization" (Coulson 112). Such a place, such an ethos could not create true believers and followers and was repelling rather than attracting. Newman rightfully claimed that such a Church cannot evoke responsibility or personal response among its followers. Being a believer could not be made a personal task unless each person could feel the urge of his or her personal call to responsibility. In default of real participation-as another prominent Victorian noted-people "fail to distinguish the essential from the accidental, and who cling to their religion, not for its substance, but for its appendages" (Acton 83). The Church did not seem ready for the role of the educated laity. ${ }^{3}$

Nevertheless, it was the Roman Church that Newman had found as the right place, indeed a breeding ground for the development of active participation. He found such examples as he scrutinized the history of the first witnesses of the united Church.

\section{CONCLUSION}

We have been considering throughout this text the significance of places in the life of the prominent Victorian, St John Henry Newman. He firmly believed in the genii locorum, in the spirit of the ethos in which he lived. Accordingly, it was important for him to realize what kind of place he was living in. The human person lives not so much amid ideas as among living human beings. They all provide examples and testimonies of loyalty or betrayal, of human prowess and dignity or human misery. Newman lived in a very interesting era of multifarious re-evaluations and re-definitions. Indeed, it was a very revolutionary period and a very dynamic world.

\footnotetext{
${ }^{3}$ Mary Craig describes the situation in Poland at the time of Cardinals Wojtyła and Wyszyński, for it seems that two models of pastoral work was at stake then. Let us read a passage from her book: "Wyszynski came to power at a time when a monolithic Church was being threatened by a secular monolith and could only be preserved intact by strong leadership. Confrontation was almost second nature to him. Wojtyla, less of a pragmatist, more of a thinker, came to authority at a very different time, when the Church of Pope John was re-thinking its role vis-à-vis the world, and the world itself was weary of confrontation" (Craig 124). Of course, writers and journalists have the right to put forward their own interpretation. The communist authorities eagerly took advantage of any differences among the Church hierarchy, but we should run the risk of an overinterpretation if we sought to read in some hostile animosities between the two cardinals.
} 
In all these re-definitions the person must be aware of what he is and whether he realizes the truth he is assenting to. The person is constantly confronted with his changing milieu, under many influences, and yet he must stand firmly amid the rich panorama of circumstances. The three milieus under discussion here were in Newman's life important genii locorum, well- or malfunctioning systems which exerted their influence on the people involved in them. His family home, with its atmosphere of love and acceptance; the university and the Anglican Church imbued with the intellectual atmosphere of modernity failed to respond to the demands of the time. Newman wished to present himself, if I may say so, to his posterity as a living testimony that no matter what genii locorum are granted to us, we are capable of reaching our personal destiny. We have been endowed with the right faculties with which we can bring our persons to the maturity of our personal callings.

John Henry Newman had eventually found the right genius loci in the Roman Catholic Church. This Church represented for him the historical continuity of the primitive Church. Indeed, for a modern self, lost amid the whims of private judgment and no fulcrum to hold on to, it must have been a symbolical foundation. The starting point for the modern self is functional disarrangement. The intellectual nutrition provided by modern theories was very inadequate; Newman supported his arguments by the testimony of his personal example.

\section{WORKS CITED}

Acton, John E. Essays on Church and State. The Viking Press, 1953.

Berlin, Isaiah. Four Essays on Liberty. Oxford UP, 1969.

Cortés, Juan D. Essays on Catholicism, Liberalism and Socialism Considered in Their Fundamental Principles. Translated by Rev. William McDonald, M. H. Gill \& Son, 1879.

Coulson, John. Newman and the Common Tradition: A Study in the Language of Church and Society. Clarendon Press, 1970.

Craig, Mary. Man from a Far Country: A Portrait of Pope John Paul II. Hodder and Stoughton, 1979.

Newman, John H. An Essay in Aid of a Grammar of Assent. Image Books, 1955.

Newman, John H. Fifteen Sermons Preached before the University of Oxford. London, 1872.

Newman, John H. Plain and Parochial Sermons. Ignatius Press, 1987.

Newman, John H. Apologia pro Vita Sua. Sheed and Ward, 1976.

Newman, John H. Certain Difficulties Felt by Anglicans in Catholic Teaching. Vol. 1, Longmans, Green Co, 1891.

Newman, John H. Discussions and Arguments on Various Subjects. Longmans, Green Co., 1924. 
Pereiro, James. Theories of Development in the Oxford Movement. Gracewing, 2015.

Taylor, Charles. Sources of the Self: The Making of Modern Identity, Harvard UP. 1989.

Trevor, Meriol. The Pillar of the Cloud. Macmillan \& Co, 1962.

Vélez, Juan R. Passion for Truth: The Life of John Henry Newman, TAN Books. 2019.

\section{GENII LOCORUM JAKO KONIECZNA PRZESTRZEŃ I MIEJSCE LUDZKIEGO ROZWOJU}

\section{Streszczenie}

Głównym tematem tego tekstu jest znana postać wiktoriańska, John Henry Newman (1801-1890) oraz sposób, w jaki odpowiadał na swój etos. Zakłada się tutaj, że każda osoba wzrasta w konfrontacji z miejscem, w którym żyje. Miejsce to, nasz genius loci, wywiera wpływ na nasze decyzje. Najważniejszą rzeczą jest odkryć system, który to miejsce tworzy. Miejsce to może być prawdziwe lub fałszywe. Newman wysoko cenił sobie swój dom rodzinny, przyjaźni uniwersyteckie oraz Kościół jako ostateczny cel życiowej podróży. Urodził się w Kościele anglikańskim, kiedy to środowisko anglikańskie było szczególnie wrogo nastawione do katolików rzymskich. Jego osobista historia jest tak fascynująca, ponieważ pomimo wrogo nastawionego otoczenia, potrafił przewartościować własne życie.

Słowa kluczowe: etos; genii locorum; Kościół; miejsce; Newman; osoba. 